M.I. Baranov

\title{
AN ANTHOLOGY OF THE DISTINGUISHED ACHIEVEMENTS IN SCIENCE AND TECHNIQUE. PART 50: ROCKET-SPACE TECHNOLOGY DESIGNER WERNHER VON BRAUN AND HIS ACCOMPLISHMENTS IN MISSILE DESIGN
}

Purpose. Preparation of short scientifically-historical essay about one of founders of world rocket production, distinguished German-American designer of modern space-rocket technique Wernher von Braun. Methodology. Known scientific methods of collection, analysis and analytical treatment of scientific and technical information, touching becoming and development in the world of space-rocket technique and resulted in scientific monographs, journals and internet-reports. Results. A short scientifically-historical essay is presented about the distinguished German-American designer of space-rocket technique Wernher von Braun, becoming one of founders of world rocket production. Basic scientific and technical achievements of talented and purposeful scientist Doctor of Physics Wernher von Braun in area of modern rocket production, getting over on persistent initiative of the American special services after the defeat of Germany in World War II in the USA (1945) for continuation of the work in area of missile technology (he was the main designer of the German battle ballistic rocket V-2 of midrange with a liquid rocket engine (LRE), created in 1944), carrying military-strategic character by that time. It is shown that Wernher von Braun is the founder of the space program of the USA and leader of developments of the American pilot-controlled spaceships of series "Apollo" within the framework of the Lunar program of the USA. It is marked that under scientific and technical guidance of Wernher von Braun in the USA powerful launch vehicles were created with LRE of battle series «Redstone» of midrange (1958, military index of PGM-11) and space series «Saturn" (1969), due to which on a circumterrestrial orbit the first artificial satellite of the USA "Explorer-1" launched (31 January, 1958 y.), and the American astronaut Neil Armstrong first in history of humanity stepped on the surface of the Moon (20 July, 1969). Originality. Certain systematization is executed known from mass media of scientific and technical materials, touching becoming and development in 20-th century of world rocket production, at the sources of which the talented scientist Doctor of Physics and distinguished German-American designer of space-rocket technique Wernher von Braun. Practical value. Scientific popularization and deepening for the students of higher school, engineer and technical and scientific workers of physical and technical knowledge in area of world history of becoming and development of modern rocket production, extending their scientific and technical range of interests and further development of scientific and technical progress in society. References 18, tables 1, figures 10.

Key words: space-rocket technique, distinguished German-American designer of missile technology Wernher von Braun, his basic achievements in a modern rocket production, scientifically-historical essay.

Приведений короткий науково-історичний нарис про видатного німецько-американського конструктора ракетнокосмічної техніки Вернера фон Брауна, щңо став одним з основоположників світового ракетобудування. Описані основні науково-технічні досягнення Вернера фон Брауна в галузі сучасного ракетобудування, щио перебрався за наполегливою ініціативою американських спецслужб після розгрому Німеччини в Другій світовій війні в США (1945 р.) для продовження роботи в області ракетної техніки, цио носить військово-стратегічний характер. Показано, щңо Вернер фон Браун є засновником космічної програми США і керівником розробок американських космічних кораблів "Аполлон». Під його науково-технічним керівництвом в США були створені потужсні ракетоносії серіӥ "Редстоун» $i$ "Сатурн", завдяки яким на навколоземну орбіту був запущений перший штучний супутник США «Експлорер-1" (1958 р.), а американський астронавт вперше в історії людства ступив на поверхню Місяця (1969 р.). Бібл. 18, табл. 1 , рис. 10.

Ключові слова: ракетно-космічна техніка, видатний німецько-американський конструктор ракетної техніки Вернер фон Браун, його основні досягнення у сучасному ракетобудуванні, науково-історичний нарис.

Приведен краткий научно-исторический очерк о выдающемся немецко-американском конструкторе ракетнокосмической техники Вернере фон Брауне, ставщем одним из основополоэяников мирового ракетостроения. Описаны основные научно-технические достижения Вернера фон Брауна в области современного ракетостроения, перебравщегося по настойчивой инициативе американских спецслужб после разгрома Германии во Второй мировой войне в США (1945 2.) для продолюеения работы в области ракетной техники, носящей военно-стратегический характер. Показано, что Вернер фон Браун является основателем космической программы США и руководителем разработок американских космических кораблей «Аполлон». Под его научно-техническим руководством в США были созданы мощные ракетоносители серии «Редстоун» и «Сатурн», благодаря которым на околоземную орбиту был запущен первый искусственный спутник США «Эксплорер-1» (1958 2.), а американский астронавт впервые в истории человечества ступил на поверхность Луны (1969 г.). Библ. 18, табл. 1, рис. 10.

Ключевые слова: ракетно-космическая техника, выдающийся немецко-американский конструктор ракетной техники Вернер фон Браун, его основные достижения в современном ракетостроении, научно-исторический очерк.

Introduction. World literature is replete with a huge number of human stories, in the plot of which is human passion. We know how this feeling can lower a person in the «eyes» and consciousness of other people and how can raise him high above the ever-changing «ocean» of events and human emotions on our planet. Akin to human passion and the talent of man - the gift of God! Talent flashing with its «flame» of the knowledge of the world around us the human soul and pushing the chosen person to surrender and realize his planned goal by any means. Here, the direction of the goal (two extreme points of reference for it - for a good cause and the creation of weapons of mass destruction of people) and the problem 
of morality for such a person can also be moved, consciously or unconsciously, to the background. By and large, the true vocation of a person is higher and more important than the prevailing political conditions and systems in which such a person has to work and live. Wernher von Braun (his full name in German is Wernher Magnus Maximilian Freiherr von Braun), an outstanding German-American designer of rocket and space technology, turned out to be one of such talented people, to which all of the above can be fully attributed. This scientific and historical essay is devoted to brief description of the life and career of this internationally recognized scientist, Doctor of Physics and design engineer in the field of rocketry (Fig. 1).

The goal of the paper is preparation of a brief scientific and historical essay on one of the founders of world rocket production, an outstanding GermanAmerican designer of modern rocket and space technology Wernher von Braun.

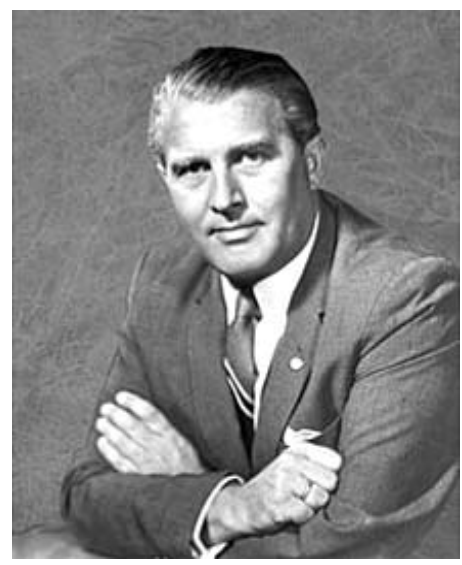

Fig. 1. Distinguished designer of rocket and space technology Wernher von Braun (23.03.1912-16.06.1977) [1]

1. The beginning of the life and career of Wernher von Braun. He was born on March 23, 1912 in the city of Wirsitz (province of Posen, the German Empire, now it is the city of Wyrzysk, Poland) [1]. His parents belonged to the ancient aristocratic families. Therefore, their son Wernher inherited the title «Freiherr», corresponding to the Baronial title. His father, Magnus von Braun (1878-1972), held the high post of Minister of Food and Agriculture in the German government of the Weimar Republic [1].

His mother, Emmy von Quistorp (1886-1959), who had royal «roots» along the line of ancestors, which ascended to Rurik [2], instilled in young Wernher a love of music and art. In the period of training (1925-1930) in a boarding school with strict Prussian orders, located near the city of Weimar, he became interested in the book by Hermann Oberth "The Rocket into Interplanetary Space» [2]. This forced him to actively engage in physics and mathematics, which he needed to independently design handicraft rockets at that time. In 1930, Wernher von Braun entered the Berlin Higher Technical School (now this is known in the world the Berlin Technical University), where he joined the research group «Space Travel Society» and together with H. Oberth (1894-1989) he participated in testing first liquid rocket engines (LRE) [1]. At this time, he firmly decided to devote his life to penetration into extraterrestrial space $[1,2]$. It is believed that it was $\mathrm{H}$. Oberth who had a great influence on the formation of Wernher von Braun as a future rocket maker. Later, Wernher von Braun wrote about this German pioneer of rocket science [1]: «... Personally, I see in him not only the guiding star of my life, but also I owe him my first contacts with theoretical and practical issues of rocket engineering and space flights». In 1932, he was admitted to the military missile scientific group of Walter Dornberger (then captain of artillery, who became Major General in 1941), engaged in the development and creation for the Reichswehr (German military) both solidfuel missiles and missiles with LRE. In April 1934, Wernher von Braun successfully defended at the Friedrich Wilhelm Berlin University his Doctoral Thesis on the topic [1] «Design, theoretical and experimental approaches to the problem of creating a liquid-fuel rocket» (at one time this Thesis was classified and its materials were not published until 1960 [2]). For this scientific work (the supervisor of this Thesis was German physicist Erich Schumann [1]), he was awarded the degree of Doctor of Physics (rocket science).

2. The main achievements of Wernher von Braun in the field of rocket science (German period 19341945). In 1933, the Nazi regime in Germany prohibited the conduct of civilian experiments in rocket production in the country and all relevant amateur scientific societies were eliminated. Rockets were allowed to build only by the military. For these purposes, in the north of Germany (on the island Usedom in the Baltic Sea with the village of Peenemünde) large German rocket center and a test site were built in 1937, the Military Head of which was W. Dornberger, and the Technical Director was Wernher von Braun $[1,2]$. Under these conditions, Wernher von Braun was forced to join the National Socialist Party of Germany (May 1937). In addition, it is believed that from May 1940 to May 1945 he was an SS officer (he began his service from the rank of Untersturmführer Lieutenant and rose to the rank of Sturmbannführer Lieutenant Colonel) [1, 2]. The specified period of work and military service of Wernher von Braun in Germany is a «black spot» in his biography (this information was subsequently hidden for a long time by the secret services from the American public). Despite this SS trail in the life of the essay's main person, Wernher von Braun and his team managed to create an A-4 (V-2) combat rocket launcher by the fall of 1944, capable of hitting cities in the UK and other countries of Europe from a long distance. The first combat missile V-2 (Fig. 2) was launched to London on September 7, 1944 (21 months after the official adoption «at the top» of this German project «The Weapon of Retribution») $[1,2]$. Note that the first launches of prototypes of the V-2 rocket from the Peenemünde test site began in October 1942 [3]. The cost of one such rocket, despite the use of free labor by prisoners in its production, amounted to 300 thousand Reichsmarks [3]. Table 1 shows the main tactical and technical characteristics of the $\mathrm{V}-2$ rocket $[3,4]$. 


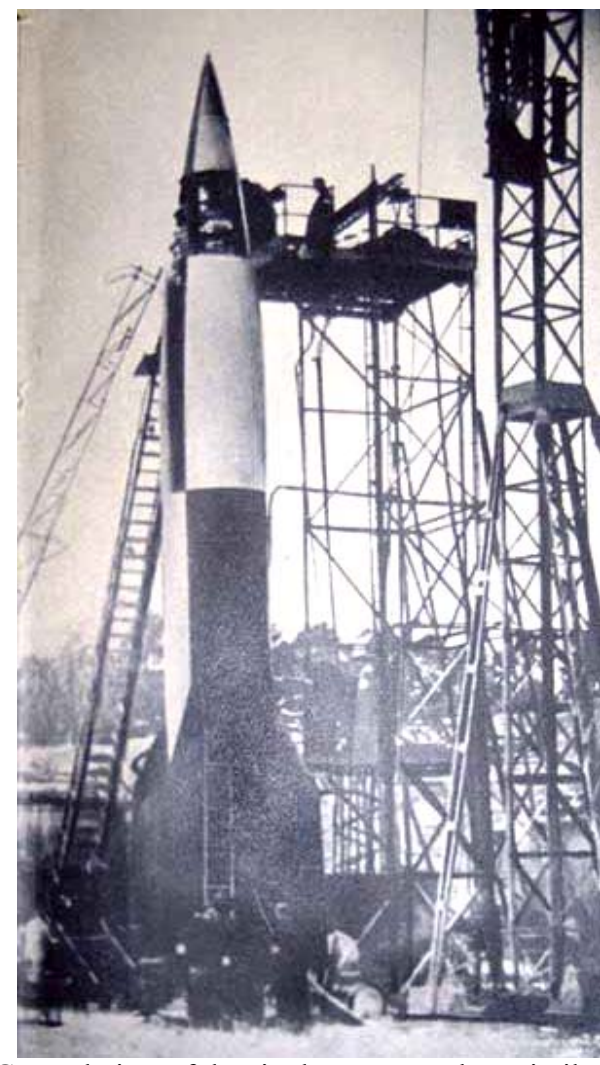

Fig. 2. General view of the single-stage combat missile V-2 with LRE during its preparation on the launch pad for launch (photo of 1944; Peenemünde test site) [3]

Table 1

The main tactical and technical characteristics of a combat German single-stage ballistic missile with LRE V-2 [3, 4]

\begin{tabular}{|c|l|c|}
\hline No. & \multicolumn{1}{|c|}{ Characteristic } & Value \\
\hline 1 & Total length, $\mathrm{m}$ & 13,9 \\
\hline 2 & Diameter, $\mathrm{M}$ & 1,6 \\
\hline 3 & Weight of the warhead, kg & 1000 \\
\hline 4 & Maximum thrust of the LRE: & \\
\hline & - near the surface of the Earth, $\mathrm{t}$ & 26 \\
\hline & - at flight altitude, $\mathrm{t}$ & 30 \\
\hline 5 & Starting weight, $\mathrm{t}$ & 13 \\
\hline 6 & Maximum range in near-earth space, $\mathrm{km}$ & 300 \\
\hline 7 & Type of liquid fuel for LRE & $80 \%$ ethanol \\
\hline 8 & Mass of liquid fuel, kg & 3600 \\
\hline 9 & $\begin{array}{l}\text { Mass of oxidizer (liquid oxygen) for } \\
\text { LRE, kg }\end{array}$ & 5000 \\
\hline 10 & $\begin{array}{l}\text { Maximum flight speed in near-earth } \\
\text { space, } \mathrm{m} / \mathrm{s}\end{array}$ & 1500 \\
\hline 11 & LRE operating time, $\mathrm{s}$ & 65 \\
\hline 12 & Maximum flight height above Earth, $\mathrm{km}$ & 95 \\
\hline 13 & Speed when meeting with hit target, $\mathrm{m} / \mathrm{s}$ & 800 \\
\hline
\end{tabular}

From the data of Table 1 it can be seen that the V-2 rocket, when flying in near-Earth space, could move at speed of about $5,400 \mathrm{~km} / \mathrm{h}$, which significantly exceeded the speed of sound in air, which at normal atmospheric conditions is about $1,194 \mathrm{~km} / \mathrm{h}(331.8 \mathrm{~m} / \mathrm{s})$ [5]. The $\mathrm{V}-2$ missiles were made by foreign workers, prisoners of war and prisoners of concentration camps at the huge underground factory Mittelwerk near the city of Nordhausen in German Thuringia [3]. The design capacity of this plant was up to 30 rockets per day. In 1944 , the power of this military plant was brought to release 600 rockets per month [3]. German specialists involved in the V-2 missile solved an important and fundamental task: ensuring its launch from the vertical position on the launch pad $[3,4]$.

Why is this combat single-stage ballistic missile called the V-2? It is believed that this name comes from the first letter of the German word «Vergelfungswaffee», meaning «Weapon of Retribution» [2]. By the way, the German competitors of Wernher von Braun, engaged in the development and creation of only ballistic missiles in Germany, from the air force set up an industrial production of combat projectiles (cruise missiles), which they called V-1 a little earlier [2, 6]. Note that on June 13, 1944, London was subjected to the first bombardment of $\mathrm{V}-1$ cruise missiles. However, the effect of the combat use of German V-1 missiles with ground targets was extremely weak [2, 3]: such missiles flew at subsonic speeds and could be relatively easily hit by anti-aircraft forces; their accuracy in hitting the target was low; the autonomous mechanism for controlling their flight was poorly protected from external electromagnetic interference (in this connection, due to the directional impact of the English radars on them, they fell off the flight path and often fell into the sea). The V-2 ballistic missiles have no these disadvantages (project scientific manager for its development was Wernher von Braun; military and administrative Head of this project was Wehrmacht Lieutenant General W. Dornberger), including a «mechanical» computer, a turbopump unit, gyros, electromechanical controls of the flight of a rocket, a cooled combustion chamber of liquid fuel in the LRE, and many other devices characteristic of a modern powerful rocket with LRE [7]. Ballistic missiles V-2, made in a total quantity of up to 4300 pcs. (for the period September 1944 - March 1945), inflicted on the British city of London (from the occupied territory of the north of France the said German rocket reached it in just about 6 minutes) and the Dutch city of Antwerp enormous material damage and irreparable human damage (13029 people became their victims) $[2,3]$. It should be noted that because of the relatively quick, primarily due to the offensive actions of the USSR and its main allies (USA and Great Britain), approaching the end of the Second World War in Europe and the collapse of Nazi Germany that followed in May 1945, the German strategic project (the Head of works was W. von Braun), associated with the development and creation of an intercontinental twostage ballistic missile A-9/10 with a range of $5000 \mathrm{~km}$, was unrealized $[2,4]$.

According to the authoritative opinion of the prominent Soviet specialist in the field of rocket engine technology (the General Designer of the RD-253 type LRE widely known all over the world [6]), twice Hero of Labor, Academician of the Academy of Sciences of the USSR V.P. Glushko [2]: «... The creation of the $V-2$ 
rocket was a great technical achievement in the field of rocket production».

According to archival data, a prototype of the V-2 rocket launched from the German Peenemünde rocket test site on October 3, 1942 exceeded the speed of sound in the air for the first time in the history of rocketry [7]. It is known that space begins from a height of $70 \mathrm{~km}$ above the surface of the Earth $[6,7]$. In this regard, it can be argued that the V-2 rocket is the first apparatus of terrestrial origin that has fallen into outer space. The reason for this is that the prototype of the V-2 rocket launched with instruments on February 17, 1943 reached a height above the Earth of $190 \mathrm{~km} \mathrm{[7].} \mathrm{By} \mathrm{the} \mathrm{way,}$ Wernher von Braun launched to the same height later in the USA with the help of his new Redstone ballistic missile also the first two American astronauts A. Shepard (May 5, 1961, $185 \mathrm{~km}$ ) and V. Grissom (July $211961,190 \mathrm{~km})$ [7].

It is also necessary to point out that military rocket technology in the former USSR and the USA began with the V-2 ballistic missiles, the technical documentation for which, and the very prototypes of which were promptly obtained by the intelligence services of these countries, were carefully studied and used in the respective design offices [4, 7]. Note that the first Soviet ballistic missile P-1 was an exact replica of the German V-2 missile, only manufactured at our factories according to domestic drawings and of domestic materials $[4,7]$.

Was the relatively young 32-year-old and undoubtedly talented Wernher von Braun the «father» of the V-2 ballistic missile in 1944 (the year when the combat model of the V-2 missile was created)? According to the memoirs of the military and administrative Head of work on the creation of this German rocket W. Dornberger [8]: «... The V-2 was directly developed by the design bureau led by Walter Riedel. Successes in designing the engine for this rocket were mainly due to the works of Walter Thiel. Although von Braun and Riedel also contributed many ideas to the design of the engine. Riedel, with his calm nature, deep thinking and extensive knowledge, was a good counterbalance to the overly temperamental von Braun. Von Braun's main concern was the elimination of the difficulties encountered in the work. Von Braun's talent as a leader was not without flaws. His undoubted leadership qualities were not always accomplished. However, Wernher von Braun's personal contribution to all areas of the development of the $V$-2 rocket was decisive, guiding, and truly invaluable». Summarizing the scientific and technical history of the creation of the V-2 rocket, the former German Wehrmacht Lieutenant General Walter Dornberger (Head of the German Peenemünde test site) in his memoirs came to the deeply thoughtful conclusion that its creation cannot be associated with one person [8]: «... Days of lonely creative geniuses are over. Such achievements can only be the fruit of the work of a team of unknown researchers and experts who can work side by side without self-indulgence».
On May 2, 1945, in the Bavarian Alps (southern Germany), Wernher von Braun, along with the V-2 rocket documentation and most of the specialists (first out of 115 , and later out of 650 people) from the German rocket group, surrendered to the troops of the advancing American the army (specifically the militants of the 44th US Infantry Division), whose intelligence services already had instructions for a targeted «hunt» for them $[3,7]$. In the course of secretly planned US operations, codenamed «Paperclip», they were all taken out of defeated Germany to America and were placed first in Fort Bliss, Texas, which became a major base of the US Army [3]. The US Department of State, through the Joint Intelligence Objectives Agency, developed fictitious biographies for all 765 German experts in rocket technology and removed information about their connection with the Nazi regime in Germany [1, 2]. In this way, the American government provided the German rocket scientists, who had become «state scientists», with the necessary security guarantees for their work in the United States. To this we should add the fact that in 1945, 350 railway cars with valuable technical equipment and nodes for V-2 missiles were delivered by sea to the USA [9].

3. The main achievements of Wernher von Braun in the field of rocket science (the American period 1945-1975). According to the available historical materials typical for Wernher von Braun was that if he set himself a goal, he always achieved it [9]. Largely due to his will and purposefulness, and not only to his talent, he, as a born scientific leader and design engineer, has reached unattainable for many super-high scientific and technical «peaks» in the field of rocket production. Once, on the slope of his long years, an outstanding Soviet aircraft designer, Colonel-General-Engineer, three times Hero of Labor, Academician of the Academy of Sciences of the USSR S.V. Ilyushin [10], personally and well acquainted with many outstanding designers of the USSR in the field of aviation and rocket technology, in an interview with students-graduates of the N.E. Zhukovsky Air Force Academy about the main personal qualities of the Chief Designer said that for such a person [7]: «... The main quality is the great, all-consuming desire to become the Chief and not stop at nothing on the way to his goal». The author thinks that in relation to the outstanding designer of rocket and space technology, Wernher von Braun, our patriarch of aircraft construction, as we say, got into the bull's eye. It is this personal quality that was central and characteristic of the leader we are considering in the field of world rocket production.

From September 1945, Wernher von Braun headed the US Army Design and Development Service at the designated Fort Bliss, located near the White Sands Proving Ground, New Mexico [1]. It was from this military test side that Wernher von Braun launched his ballistic missiles. Apparently, these places should be considered the «cradle» of American rocket production. From 1950, together with his German fellow rocket 
engineers (Fig. 3), he began working at the Redstone Arsenal (Huntsville, Alabama) [3].

Paying tribute shown in Fig. 3 rocket engineers, we indicate their positions in the Redstone Arsenal of the United States [3]: E. Stuhlinger - Director of the Office of Scientific Research; H. Hoelzer - Director of the Computing Center; K. Heimburg - Director of the Testing Laboratory; E. Geissler - Director of the Aeroballistic Laboratory; E. Neubert - Director of the Laboratory of Reliability and Systems Analysis; W. Haeussermarn Director of the laboratory of Guidance and Control; Wernher von Braun - Chief Designer and Director of Development Division; W. Mrazek - Director of the Laboratory of Design and Mechanics; H. Hueter Director of the Laboratory of Ground Systems; E. Rees Deputy Director of the Development Division; K. Debus - Director of the Missile Launch Laboratory; H. Maus Director of the Laboratory for the Production and Assembly of Missiles.

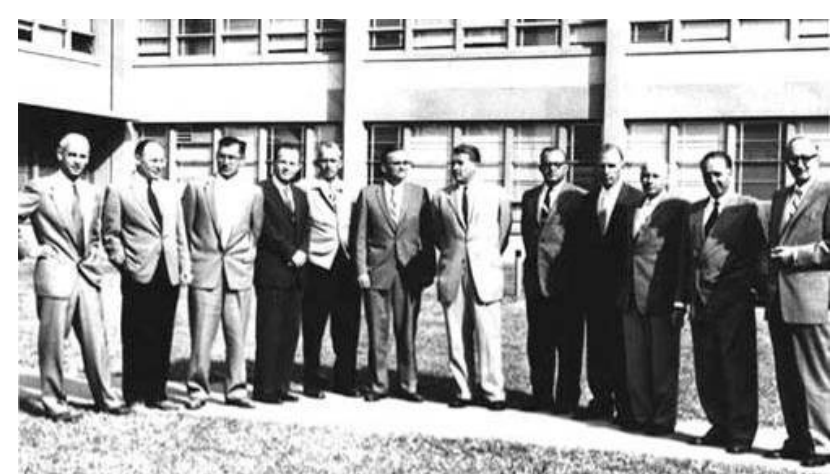

Fig. 3. Twelve main German rocket engineers, who replaced the Peenemünde Rocket Center (Germany) with the Redstone Arsenal of the USA (rare NASA photo; from left to right: Ernst Stuhlinger; Helmut Hoelzer; Karl L. Heimburg; Ernst Geissler; Erich W. Neubert; Walter Haeussermarn; Wernher von Braun; William A. Mrazek; Hans Hueter; Eberhard Rees; Kurt

Debus; Hans H. Maus; 1959, Redstone Arsenal, USA) [3]

Already, only by the names of the services headed by these rocket men can one indirectly judge the complexity of the scientific and technical tasks facing these developers of US military ballistic missiles, who soon became the first German-American explorers of near-Earth space. In 1951, by the German rocket men shown in Fig. 3, the first American Viking ballistic missile was created, which developed a speed of up to 1.8 $\mathrm{km} / \mathrm{s}(6480 \mathrm{~km} / \mathrm{h})$ [6]. Of course, this speed was significantly lower than the first cosmic speed, which is about $7.9 \mathrm{~km} / \mathrm{s}(28440 \mathrm{~km} / \mathrm{h})$ [5]. In 1952, under the leadership of Wernher von Braun, a Redstone combat ballistic missile (PGM-11 military index) was created in the United States (Fig. 4) [11], which was used by the US Army in the period 1958-1964 and used at the launch on January 31, 1958 of the first American artificial satellite of the Earth «Explorer 1» (weight -14 $\mathrm{kg})[6,12,13]$. The US launch of this artificial satellite was the American response for the USSR, which launched on October 4, 1957 with the help of an intercontinental ballistic missile P-7 the world's first artificial satellite of $83.6 \mathrm{~kg}$ weight $[6,7]$.

We point out that Redstone combat ballistic missiles (PGM-11) with a thermonuclear warhead W-39 aboard with a power of $4 \mathrm{Mt}$ of TNT were deployed in West Germany [11]. The range of these medium-range missiles was up to $350 \mathrm{~km}$, and their accuracy at hitting the target was up to $300 \mathrm{~m}$ (at that time, this accuracy was impressive) [11].

The launch of the first US cigar-shaped artificial satellite Explorer-1 (Fig. 5), which had $8.3 \mathrm{~kg}$ of scientific instruments on board, marked the beginning of space flights in the United States, as well as scientific research of space by scientists (for example, the study of the atmosphere, ionosphere and magnetosphere of Earth, energy particles, meteorites and monitoring of solar radiation) [13]. By the way, with the help of the «Explorer 1» artificial satellite which flew around the Earth in 114 minutes on an elliptical orbit at altitudes of $362-2565 \mathrm{~km}$, the Van Allen radiation belt was first discovered [14].

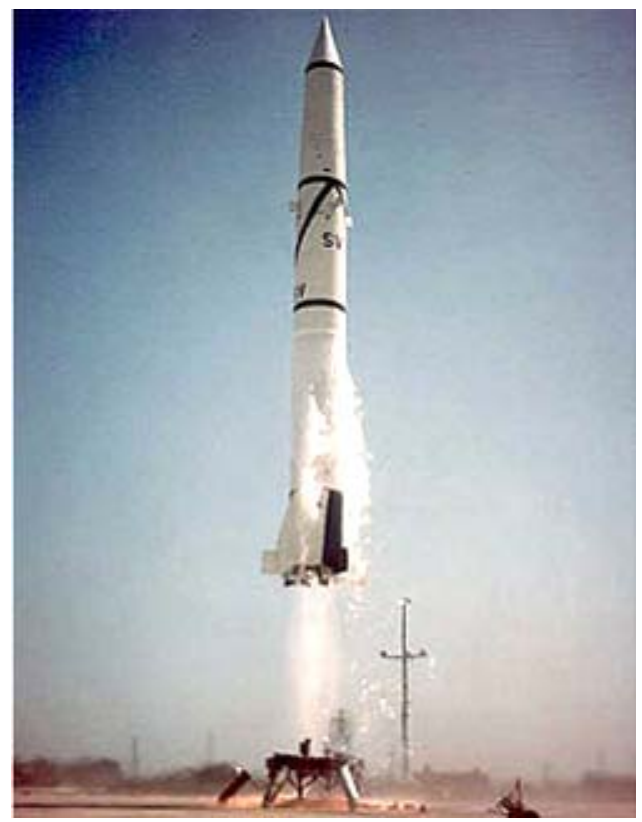

Fig. 4. The start of the Redstone medium-range ballistic missile (length $-21.1 \mathrm{~m}$; diameter $-1.78 \mathrm{~m}$ ) with a detachable warhead created in the USA under the scientific and technical guidance of Wernher von Braun [11]

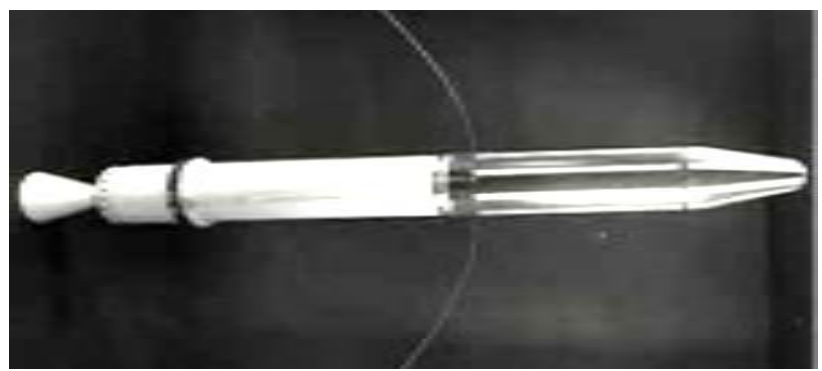

Fig. 5. External view of the first American artificial satellites Explorer-1 (1958, gross weight - 14 kg, USA) [14]

Note that since 1955, Wernher von Braun is a US citizen, the mention of whose name in the press was prohibited by special services [3]. In 1960, the rocket 
men, led by Dr. Wernher von Braun, were transferred to the National Aeronautics and Space Administration (NASA) of the United States [15]. So the rocket genius (German Baron by birth), who has now officially become the American designer of rocket and space technology, began to serve NASA, a prestigious US government agency, with full scientific and engineering efficiency. During this period, NASA created the Marshall Space Flight Center, Huntsville, Alabama, as the first Director of which Wernher von Braun was appointed [15]. Now, under his leadership, about 2 thousand people worked, and the leaders of all 30 Departments of this US Space Center were his German colleagues, who, like him in 1955, received American citizenship. At this time, another Soviet call came in the US in the space race: in the USSR on April 12, 1961, into a near-earth orbit using a threestage ballistic missile P-7 and the Vostok-1 spacecraft (their chief designer was an outstanding Soviet designer of rocket and space technology, twice Hero of Labor, Academician of the Academy of Sciences of the USSR S.P. Korolev), the first Soviet cosmonaut (astronaut in «American») in the history of mankind Yu.A. Gagarin was launched $[6,7]$. After the shock from such a course of international events in the field of space exploration in the United States (and throughout the world), Wernher von Braun suggested to the US leadership to carry out several suborbital space flights for the US astronauts with the help of the Redstone launch vehicle. These flights under the direction of Wernher von Braun were performed on May 5, 1961 (A. Shepard traveled in space at an altitude of $185 \mathrm{~km}$ ) and on July 21, 1961 (V. Grissom traveled in space at an altitude of $190 \mathrm{~km}$ ) [7]. But this was not enough for ambitious America. In the conquest of space by mankind by such the richest country on our planet as the USA, it was necessary to surprise the world with some kind of a grand event. And such a planned event was found, discussed by experts and voiced in the keynote speech of US President John F. Kennedy [1]: «... For the prestige of the nation, it is necessary to ensure the landing of the American astronaut on the Moon until 1970». For the practical implementation of this great goal, the US Lunar Program was prepared, Wernher von Braun was appointed the Head of which [1].

Huge financial resources were allocated for the implementation of the US Lunar program by the US government in the 1960s - about USD 20 billion USA (for comparison, we point out that for the creation in US of the first plutonium and uranium atomic bombs in the United States under the secret Manhattan Project about USD 2 billion budget allocations were allocated [16, 17]) [15]. In order for the United States to fulfill this national space program, a new powerful launch vehicle was needd, called Saturn-V Wernher von Braun was appointed the chief designer of this launch vehicle intended for manned flights to the Moon with the help of Apollo spacecrafts. US President John F. Kennedy (Fig. 6) paid close attention to the development work carried out by NASA in the framework of the Lunar Program $[8,18]$.

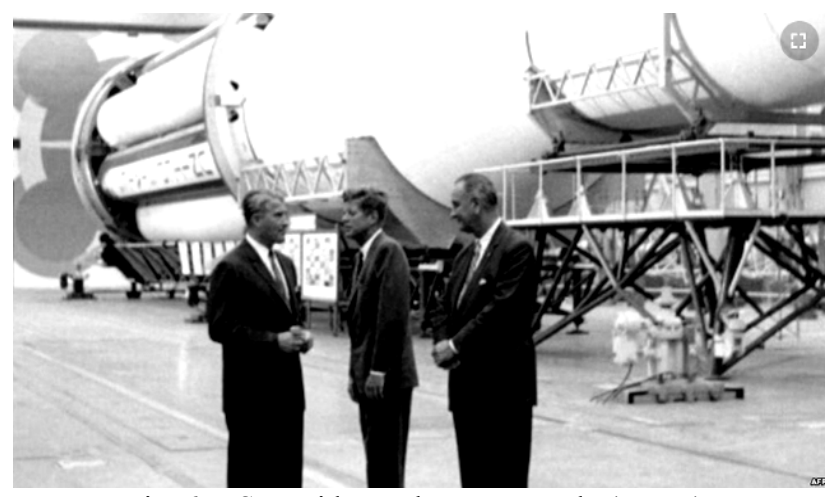

Fig. 6. US President John F. Kennedy (center),

Chief Designer of the American Saturn-V launcher Wernher von Braun (left) and US Vice President

Lyndon Johnson (right) in the assembly and test building with a prototype of this launch vehicle (1962, the spaceport at Cape Canaveral, Florida, USA) [8]

Everything in our world is relative. So, the German rocket V-2 with the LRE height in a 6-storey house (chief designer - Wernher von Braun; year of creation - 1944) was able to «throw» at a speed of about 5,4 thousand $\mathrm{km} / \mathrm{h}(1.5 \mathrm{~km} / \mathrm{s})$ in the Earth's atmosphere 1 ton of payload for a distance of about $300 \mathrm{~km}$ (see Table 1). Created in the USA the Saturn-V launch vehicle with LRE of height of 33-storey building (chief designer Wernher von Braun; year of creation 1969) was able to deliver 50 tons of payload at a speed of about 40,4 thousand $\mathrm{km} / \mathrm{h}(11.2 \mathrm{~km} / \mathrm{s}$, corresponding to the second space speed [5]) in space at a distance of about 384 thousand $\mathrm{km}$, equal to the average distance of the Moon from the planet Earth [8]. It is clear that in 25 years (for the period 1944-1969) of active scientific and technical work in the field of rocket technology, Wernher von Braun achieved incredible results: to ensure the increase in the velocity of movement of a multi-ton rocket more than 7 times (from 1.5 to $11.2 \mathrm{~km} / \mathrm{s}$ ); increase the mass of payload delivered by a rocket by 50 times (from 1 to 50 tons); to increase the range of delivery of a payload by a rocket by 1,280 times (from 0.3 to 384 thousand $\mathrm{km}$ ). Just a gigantic evolution of integral indicators in the field of modern rocket and space technology!

Now it becomes clear the answer to the question of why the United States ahead of the USSR in landing on the surface of the Moon a representative (resident) of our planet. They were ahead due to the superiority in the operational creation by the American specialists of a powerful launch vehicle. The organizational and scientific and technical talent of designer Wernher von Braun in this advance is paramount. As a result, on July 20, 1969, the American Apollo-11 spacecraft with three astronauts on board (Neil Armstrong, Michael Collins and Buzz Aldrin), driven by the energy of the Saturn-V launch vehicle in outer space, carried out with the help of a descending lunar module Eagle with two astronauts on board (N. Armstrong and B. Aldrin) landing on the lunar surface $[6,15]$. In Fig. 7 the moment of N. Armstrong walking on the Noon is captured [9]. 


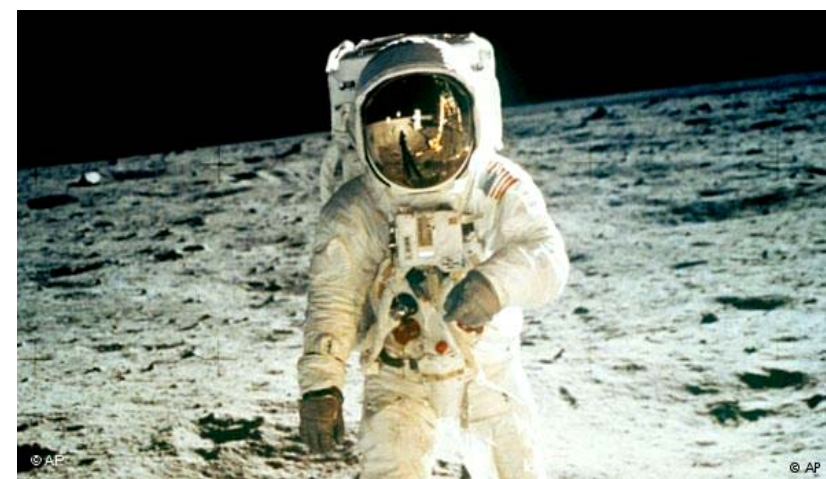

Fig. 7. Historical moment: for the first time in the history of mankind, the American astronaut Neil Armstrong was on the lunar surface (a photo of July 20, 1969, Moon)

It is interesting for the reader to quote the remarkable, inspired and truly pathetic words of the American astronaut Neil Armstrong (August 5, 1930 August 25, 2012), the first earthman to enter the lunar soil, after his walk for 2 hours 41 minutes in a spacesuit on the surface of the Moon [6]: «... It was a small human step. But it was a great leap for humanity».

For this flight of the American Apollo-11 spacecraft, Wernher von Braun in 1969 was awarded the NASA medal «For Distinguished Service» [1]. From January 1970, he becomes the NASA Deputy Assistant Administrator for planning. Wernher von Braun reached the top of his career in 1972 (Fig. 8) when he became the NASA Deputy Director and at the same time the Head of the US space center at Cape Canaveral, Florida [2]. However, in the same 1972, in the conditions of the economic crisis, he was offered to cancel expensive flights to the Moon with the aim of studying it and to engage in more economically advantageous launches of reconnaissance and scientific-technical satellites of the Earth [2, 9].

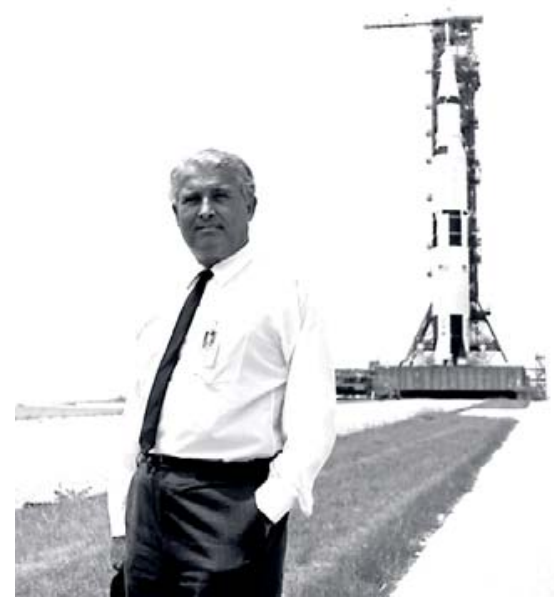

Fig. 8. The finest hour of the twentieth-century rocket and space technology designer Wernher von Braun during the leadership of the spaceport at Cape Canaveral, on the launch pad of which,

at the time of the photo, its launch vehicle Saturn-V was preparing to launch.(1972, USA) [2]

The «father» of the US space program apparently did not agree with such a commercial statement of the issue in the field of space exploration and was soon dismissed by the NASA leadership [2]. He did not remain without work: representatives of the American business, who knew his business skills well, immediately offered him the position of Vice-President of Fairchild Space Industries, Germantown, Maryland engaged in the production of aerospace equipment [15]. Then the «black» life strip came: he was diagnosed with a serious illness - pancreatic cancer. Virtually the entire 1973 went to Wernher von Braun for surgery and intensive treatment of this disease. In 1974, despite the weakened health, he continued to work on the project of a new satellite, and gave all his free time to flying on his own glider [2].

In Fig. 9 space dreamer and a true fan of space exploration Wernher von Braun is depicted against the backdrop of the impressive design of the Saturn-V heavy American launch vehicle, for the development and creation of which he, as its chief designer, gave so much strength and health.

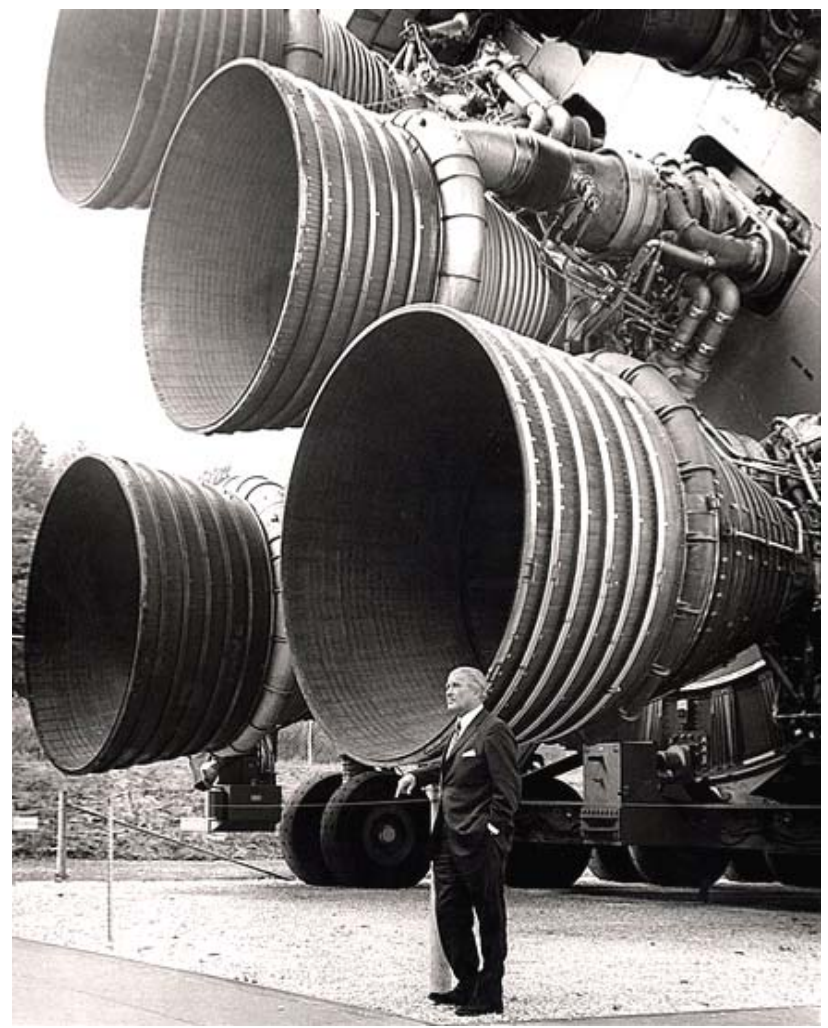

Fig. 9. Outstanding designer of rocket and space technology Wernher von Braun near with his main space «brainchild» in the United States - the museum exhibit of the powerful launch vehicle Saturn-V (in the foreground - nozzles of combustion chambers of LRE fuel of its first stage) [1]

4. Awards and honors of Wernher von Braun. He didn't have many of them, he had only the awards and badges of the Federal Republic of Germany and the United States [1]:

- The Grand Cross of the Order of Merit for the Federal Republic of Germany (1951);

- Order «For Services to the Federal Republic of Germany» (1951);

- NASA Medal «For Distinguished Service» (1969); 
- Elliott Cresson Medal (1962);

- Langley Gold Medal (1967);

- Wilhelm Exner Medal (1969);

- National Science Medal of the United States (1975);

- Werner von Siemens Ring (1975).

On June 16, 1977, after a long struggle with serious illness, Wernher von Braun died. He was buried with honors at the Ivy Hill Cemetery, Fig. 10 in Alexandria, Virginia, USA [1]. On the NASA website, this great rocket technology designer is given the following characteristic [15]: «... Without any doubt, Wernher von Braun was the greatest scientist in the field of rocket physics in history».

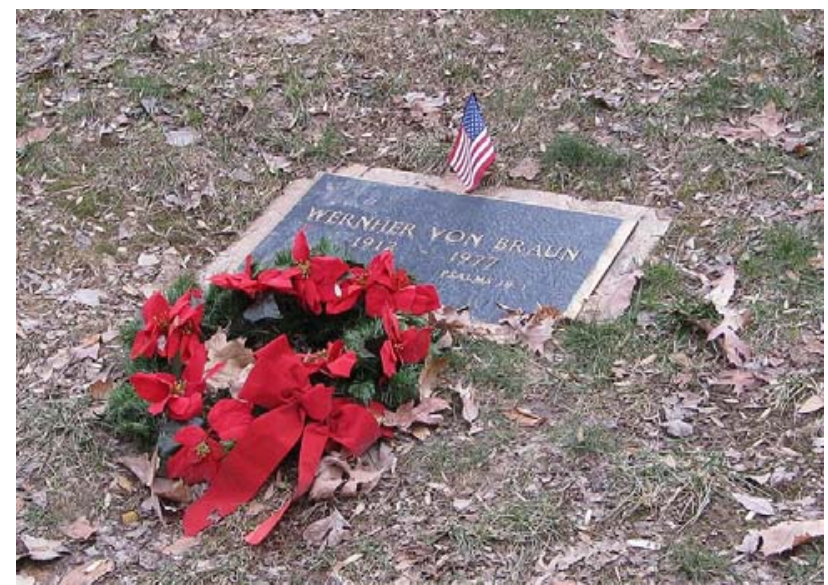

Fig. 10. A modest gravestone on the grave of Wernher von Braun, an outstanding designer of the 20th century in the field of rocket and space technology (1977, Ivy Hill Cemetery, Alexandria, Virginia, USA) [1]

In 1977, US President Jimmy Carter responded on the death of Wernher von Braun as follows [8]: «... For millions of Americans, the name of Wernher von Braun was inextricably linked with the exploration of space by the American nation and the creative use of technology. He was not only a skilled engineer, but also a man with a bold vision. His inspirational leadership style helped us to mobilize and preserve the efforts that made us reach the Moon and move on. Not only the representatives of our nation, but also the people of the whole Earth, benefited from the fruits of his work. His legacy will continue to benefit us»).

The famous American science fiction writer Arthur Clark wrote about the hero of our essay [8]: «... There are only a few people in the entire history of our civilization who have left behind such a set of achievements as Wernher von Braun, or who could themselves see such a complete triumph of their ideas and the realization of their dreams. His example will inspire future generations of people. The fact that I happened to call him my friend, I consider one of the greatest successes in my life».

The current generations of earthlings will remember Wernher von Braun as a great man who helped people pave the «road» into space and get them to often seen by us on the night sky the satellite of our planet Earth - the Moon. They will remember him as a person who has managed in his life, in spite of everything, to realize not only his own, but also the dream of all mankind - to penetrate into other worlds of the Universe. He managed to bring a bright «flame» from the torch of his scientific and technical knowledge to the consciousness of all earthlings.

Conclusions. Wernher von Braun, a talented scientist and Doctor of Physics, as a German designer of rocket technology (chief designer of a single-stage ballistic V-2 missile with LRE created in Germany in 1944) and as an American (from 1955) designer of rocket-space technology (chief designer of the threestage, high-power Saturn-5 launch vehicle with LRE, created in the USA in 1969, and the US manned space spacecraft Apollo), which provided for the first time in the history of mankind the landing of the planet Earth's resident Neil Armstrong on the ground of the Moon, became one of the founders of modern world rocketry. The outstanding results of his fruitful work on American soil became the worldwide scientific and technical foundation for the further conquest and study of the near and far space of our Universe by other scientists and designers of rocket and space technology.

\section{REFERENCES}

1. Available at:

$\underline{\text { https }}$

https://en.wikipedia.org/wiki/Wernher_von_Braun (accessed 16 May 2018).

2. Available

at:

http://historius.narod.ru/spravka/braun/index.htm (accessed 22 February 2018). (Rus).

3. Available at: http://osiktakan.ru/1-isz3 1.html (accessed 10 March 2018). (Rus).

4. Chertok B.E. Rakety i liudi. V 4-kh tomakh. Tom 1 [Rockets and people. In 4-th volumes. Vol. 1]. Moscow, Mashinostroenie Publ., 1999. 416 p. (Rus).

5. Kuhling H. Spravochnik po fizike. Per. s nem. [Dictonary on Physics. Translated from German]. Moscow, Mir Publ., 1982. 520 p. (Rus).

6. Baranov M.I. Antologiia vydaiushchikhsia dostizhenii v nauke i tekhnike: Monografiia $v$ 2-kh tomakh. Tom 2. [An anthology of outstanding achievements in science and technology: Monographs in 2 vols. Vol.2]. Kharkov, NTMT Publ., 2013. 333 p. (Rus).

7. Available

at:

https://zn.ua/SOCIETY/samaya bolshaya tayna sovetskoy rak etnoy tehniki.html (accessed 21 April 2018). (Rus).

8. Available at: https://www.golos-ameriki.ru/a/von-braunannivesary-2012-03-24-144087166/666031.html (accessed 06 March 2018). (Rus).

9. Available

https://www.dw.com/ru/вернер фон браун от фау-

2 до_полетов_на_луну/а-4752846 (accessed 11 Мау 2018). (Rus).

10. Available

http://www.ilyushin.org/about/history/biography (accessed 28 January 2018). (Rus).

11. Available at: https://en.wikipedia.org/wiki/PGM11_Redstone (accessed 15 February 2018).

12. Available at: https://history.wikireading.ru/80560 (accessed 14 March 2018). (Rus). 
13. Available https://www.gazeta.ru/science/2018/01/31_a 11631439.shtml (accessed 02 May 2019). (Rus).

14. Available at: https://ecoruspace.me/Эксплорер-1.html (accessed 28 September 2018). (Rus).

15. Available at: https://topwar.ru/11774-verner-fon-braunraketnyy-baron-na-sluzhbe-nasa.html (accessed 11 August 2018). (Rus).

16. Baranov M.I. An anthology of outstanding achievements in science and technology. Part 7: Nuclear and thermonuclear weapon creation. Electrical engineering \& electromechanics, 2012, no.2, pp. 3-15. (Rus). doi: 10.20998/2074272X.2012.2.01.

17. Baranov M.I. An anthology of the distinguished achievements in science and technique. Part 40: The scientific opening of the method of explosive implosion for the obtaining above critical mass of nuclear charge and Ukrainian «track» in at: the «Manhattan» American atomic project. Electrical engineering \& electromechanics, 2017, no.5, pp. 3-13. doi: 10.20998/2074-272X.2017.5.01.

18. Pishkevich D. Verner fon Braun. Chelovek, kotoryi prodal Lunu [Vernher von Braun. Man which sold the Moon]. Moscow, Popurri Publ., 2011. 360 p. (Rus).

Received 08.04.2019

M.I. Baranov, Doctor of Technical Science, Professor,

Scientific-\&-Research Planning-\&-Design Institute «Molniya»,

National Technical University «Kharkiv Polytechnic Institute», 47, Shevchenko Str., Kharkiv, 61013, Ukraine, phone +380 577076841 ,

e-mail: baranovmi@kpi.kharkov.ua

How to cite this article:

Baranov M.I. An anthology of the distinguished achievements in science and technique. Part 50: Rocket-space technology designer Wernher von Braun and his accomplishments in missile design. Electrical engineering \& electromechanics, 2019, no.4, pp. 3-11. doi: 10.20998/2074-272X.2019.4.01. 